myocardial infarction. ${ }^{29}$ However, cardiac rupture as described in the eighteenth century must sometimes have been an entity different from the current one. Of the mere half dozen cases documented by Leibowitz, two involved the right ventricle, one incidentally resulting in the sudden demise of King George II. ${ }^{30}$ In an era in which rheumatic heart disease was prevalent, infections common and bacterial endocarditis incurable, myocardial abscesses were a possible cause of cardiac rupture. Morgagni did describe a single case in which a tendinous left ventricular wall suggested presence of scarring as a sequel of myocardial infarction and his finding of a left ventricular aneurysm in another autopsy could imply a similar cause. ${ }^{31}$ In both of these instances the victims must have survived the episode by months, if not years. An autopsy reported by Crell stands alone in describing an intracoronary soft yellow-white body which could be extruded. It had a worm-like form and the part of the heart through which this artery passed was withered and pulpy. ${ }^{32}$ The description is compatible with either a thrombosis or with extruded contents of a ruptured soft atheromatous lesion, but it stands alone. Although most of these pathological reports were preceded by short clinical descriptions, none made reference to chest pain on effort.

In conclusion, thousands of pathological reports concerning the heart were extant from the period under consideration, notably, but not exclusively, in the writings of Bonet, Crell and Morgagni. The findings reviewed suggest that among them there were just seven autopsy descriptions that might be ascribed to myocardial infarction and that antedated Heberden's 1768 description of angina. Among the multitude of clinical descriptions accompanying the autopsy reports there were but two mentions of pain recognizable as angina pectoris having been a feature of the preceding illness, both by Morgagni and described in Chapter III. It must be noted too that in an era in which valvular disease of the heart and its infective complications were both probably much more prevalent than today, emboli, either sterile or infected, could have been the cause of myocardial infarction (although not angina of effort) with far greater relative frequency than is currently the case. Of the handful of pathological descriptions compatible with myocardial infarction that were recorded before 1768, none is necessarily secondary to coronary arterial disease.

\title{
Aortic and Coronary Ostial Stenoses
}

Aortic valve stenosis can cause angina pectoris in the absence of coronary arterial disease, but is very much rarer than coronary arteriosclerosis. It was probably less common still before the mid-eighteenth century. Arthur Boon and his colleagues and William Roberts found that risk factors for aortic stenosis included both raised

\footnotetext{
${ }^{29}$ William Harvey, Exercitatio anatomica, de motu cordis et sanguinis in animalibus, Rotterdam, Arnold Leers, 1648, pp. 99-102, 82; Giovanni Battista Morgagni, The seats and causes of diseases, transl. Benjamin Alexander, 3 vols, London, A Miller and T Cadell, 1769, vol. 1, Letter xxvii, p. 846; S F Morand, 'Sur quelques accidents remarquables dans les organes de la circulation du sang', Mémoires de l'Académie Royale des Sciences, 1732, p. 428-34.

${ }^{30}$ Leibowitz, op. cit., note 16 above, p. 82.

${ }^{31}$ Morgagni, op. cit., note 29 above, p. 846.

${ }^{32}$ Crell, op. cit., note 17 above, p. 565.
} 


\section{Rebuttals, Rejoinders and Refutations}

total serum cholesterol and hypertension. ${ }^{33}$ Reasons for considering both of these to have been rare prior to the Georgian era have been discussed in Chapters $\mathrm{V}$ and VII.

It is uncommon for coronary ostial stenosis to occur as an isolated manifestation of syphilitic cardiovascular disease. There is almost invariably an accompanying aortic aneurysm, aortic incompetence or both. Aortic incompetence could lower exercise tolerance and thereby reduce susceptibility to effort induced pain, whilst the continuous pain of aortic aneurysm would tend to mask any chest discomfort induced by exertion. Syphilis was common among the poor but angina pectoris rare. William Osler became a professor of medicine in 1874. By 1889, after fifteen years in practice at the Montreal General and Philadelphia University Hospitals, he reported having seen only one patient with angina in his hospital clinics, although syphilis had been widespread in the working population from which his hospital practice was drawn. He could not comment on his experience at the Johns Hopkins Hospital, as records of fee and non-fee paying patients were not kept separately. ${ }^{34}$

As in the western world generally, sexual relations with multiple partners is common in the United States where some 40 million people do not have access to medical care. There is a large immigrant population that came to the USA from countries where preventive medicine is virtually non-existent. Despite this, exertional chest pain as a manifestation of cardiovascular syphilis is so rare that in 1998 a patient with classical angina of effort and angiographically proven syphilitic coronary ostial stenosis was deemed unusual enough to warrant selection for a New England Journal of Medicine weekly pathological exercise. ${ }^{35}$ It would appear probable that both prior and subsequent to 1768 syphilitic coronary ostial narrowing was not associated with angina pectoris with a frequency sufficient to result in its recognition as a distinct clinical entity.

\footnotetext{
${ }^{33}$ Arthur Boon et al., 'Cardiac valve calcification: characteristics of patients with calcification of the mitral annulus or aortic valve', Heart, 1997, 78: 472-4, p. 473; William C Roberts, 'The senile cardiac calcification syndrome', Am J Cardiol, 1986, 58: 572-4.

${ }^{34}$ William Osler, 'The Lumleian lectures on angina pectoris, Lecture I', Lancet, 1910, i: 697-702, p. 698 .

${ }^{35}$ 'Case records of the Massachusetts General Hospital. Case 10-1998. A 46-year-old man with chest pain and coronary ostial stenosis', $N$ Engl J Med, 1998, 338: 897-903, p. 899.
} 